Cite this: Dalton Trans., 2014, 43, 1443

Received 18th September 2013, Accepted 30th October 2013

DOI: $10.1039 / c 3 d t 52584 h$

www.rsc.org/dalton

\section{Ruthenium(II) and osmium(II) 1,2,3-triazolylidene organometallics: a preliminary investigation into the biological activity of 'click' carbene complexes $\uparrow$}

\author{
Kelly J. Kilpin, ${ }^{\star a}$ Stéphanie Crot, ${ }^{a}$ Tina Riedel, ${ }^{a}{ }^{\text {Jonathan A. Kitchen }}{ }^{\mathrm{b}}$ and \\ Paul J. Dyson*a
}

\begin{abstract}
Taking advantage of the facile and versatile synthetic properties of 'click' 1,2,3-triazolylidene N-heterocyclic carbenes (tzNHC's), a range of new organometallic Ru(॥) and Os(॥) arene complexes containing functionalised tzNHC ligands, $\left[\mathrm{M}\left(\eta^{6}-p\right.\right.$-cymene)(tzNHC)Cl$\left.{ }_{2}\right][M=\mathrm{Ru}(\|), \mathrm{Os}(\|)]$, have been synthesised and fully characterised, including the X-ray crystal structure of one of the Os(॥) complexes. The tzNHC ligands remain coordinated to the metal centres under relevant physiological conditions, and following binding to the model protein, ubiquitin. The in vitro cytotoxicity of the compounds towards human ovarian cancer cells is dependent on the substituent on the tzNHC ligand but is generally $<50 \mu \mathrm{M}$ and in some cases $<1 \mu \mathrm{M}$, whilst still retaining a high degree of selectivity towards cancer cells over healthy cells (1.85 $\mu \mathrm{M}$ in A2780 ovarian cancer cells versus $435 \mu \mathrm{M}$ in human embryonic kidney cells in one case).
\end{abstract}

\section{Introduction}

The introduction and concurrent success of cisplatin and other platinum-based drugs in the clinic has undoubtedly transformed cancer chemotherapy. ${ }^{1}$ However, the problems associated with platinum agents, in particular their lack of selectivity towards cancer cells, has resulted in the search for alternative metal-based agents which overcome this limitation. ${ }^{2}$ In this regard, ruthenium(III) coordination compounds, notably NAMI-A and KP1019 (Fig. 1), are under clinical development. ${ }^{3,4}$ As the proposed mechanism of action of such compounds is thought to involve reduction in vivo, organometallic $\mathrm{Ru}(\mathrm{II})$ compounds have also started to attract attention. ${ }^{5,6}$ Within this field, significant efforts have centered around the development of the RAPTA-based ( $\mathrm{Ru}$ Arene PTA, pta $=1,3,5-$ triaza-7-phosphatricyclo[3.3.1.1]decane) compounds ${ }^{7}$ and ethylene diamine [Ru-arene-en $]^{+}$compounds $^{8}$ (Fig. 1). Although complexes containing ligands other than phosphines and amines have been investigated for their biological applications, ${ }^{9,10}$ one class of ligands which seems to have been largely neglected are N-heterocyclic carbenes (NHC's), which is

\footnotetext{
${ }^{a}$ Institut des Sciences et Ingénierie Chimiques, Ecole Polytechnique Fédérale de Lausanne (EPFL), CH-1015 Lausanne, Switzerland

${ }^{b}$ Chemistry, Faculty of Natural and Environmental Sciences, University of Southampton, Highfield, Southampton, SO17 1BJ, United Kingdom $\dagger$ Electronic supplementary information (ESI) available: Synthetic procedures and characterisation data, selected NMR spectra, mass spectra. CCDC 960089. For ESI and crystallographic data in CIF or other electronic format see DOI: $10.1039 / \mathrm{c} 3 \mathrm{dt} 52584 \mathrm{~h}$
}
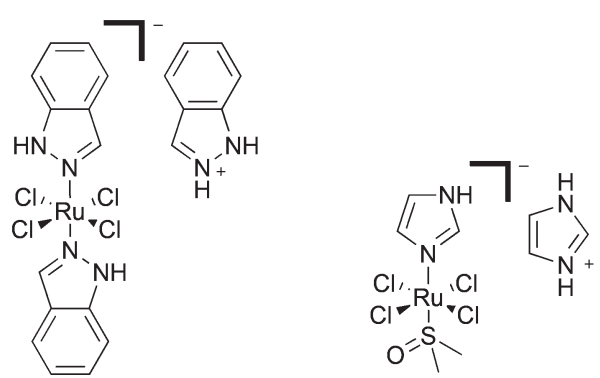

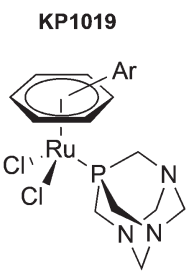

RAPTA

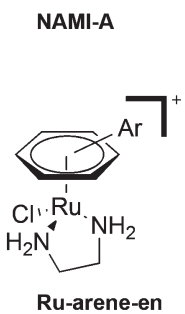

Fig. 1 Structures of selected Ru(III) and Ru(II) complexes developed as anti-tumour agents.

somewhat surprising given the large research efforts and success of Ru-NHC complexes in catalytic applications. ${ }^{11}$

The potential of metal-based NHC complexes as anti-cancer agents has been reviewed only recently, with the bulk of the research centered on either Group 10 or 11 metal complexes. ${ }^{12-14}$ However, Ru(II) NHC complexes have been touched upon, and show promising results in terms of enzyme inhibition and in vitro anti-proliferative effects. ${ }^{15,16}$ 
Furthermore, studies on zebrafish embryos have demonstrated that a selection of the complexes are essentially non-toxic, ${ }^{17}$ a somewhat significant observation considering the high toxicity of the clinically used platinum drugs.

Although relatively new, ${ }^{18}$ one class of topical NHC ligands, which to the best of our knowledge remain unexplored in biological applications, are the 1,2,3-triazolylidene N-heterocyclic carbenes. ${ }^{19,20}$ We are particularly interested in this class of NHC as the facile, modular synthetic route via the CuAAC (copper catalysed azide alkyne cycloaddition) 'click' reaction offers the ability to readily introduce a number of functional groups onto the parent triazole $\mathrm{e}^{21,22}$ and ultimately the metal complex ${ }^{23}$ e.g. for use in cellular targeting or enzyme inhibition. ${ }^{24}$ Furthermore, the resulting strong metal-ligand bond of the organometallic comple ${ }^{25}$ may prove advantageous in a highly complex biological environment.

Herein, we report the synthesis, characterisation and, to the best of our knowledge, the first investigation into the biological activity of ruthenium(II) and osmium(II) arene compounds containing 1,2,3-triazolylidene NHC ligands.

\section{Results and discussion}

\section{Synthesis and characterisation}

Ruthenium(II) and osmium(II) piano stool complexes containing functionalised tzNHC ligands were synthesised (Scheme 1) using an adaption of the procedure reported by Albrecht et al. $^{18}$

In brief, the facile one-pot CuAAC methodology described by Crowley and co-workers was used to synthesise the 1,4-disubstituted-1,2,3-triazoles 2a-e, eliminating the need to isolate the potentially explosive azide intermediates. ${ }^{26,27}$ Conversely, 2f was synthesised directly from 1-azido-2,6-diisopropyl benzene. Regioselective methylation of the triazoles $2 \mathbf{a}-\mathbf{f}$ at the $\mathrm{N} 3$ position was carried out using $\left[\mathrm{Me}_{3} \mathrm{O}\right]\left[\mathrm{BF}_{4}\right]$ to afford $\mathbf{3 a}-\mathbf{f}^{28}$ Subsequent reaction of the triazolium salts $3 \mathbf{a}-\mathbf{f}$ with $\mathrm{Ag}_{2} \mathrm{O}$, followed by addition of either $\left[\mathrm{Ru}\left(\eta^{6}-p \text {-cymene }\right) \mathrm{Cl}_{2}\right]_{2}$ or $\left[\mathrm{Os}\left(\eta^{6}-p\right.\right.$ cymene) $\left.\mathrm{Cl}_{2}\right]_{2}$, afforded the mononuclear piano stool complexes in good yields. ${ }^{18}$ Using this method we were able to introduce the simple alkyl (ethyl $\mathbf{4 a}$ and $\mathbf{5 a}$, hexyl $\mathbf{4 b}$ and $\mathbf{5 b}$, dodecyl $\mathbf{4 c}$ and $\mathbf{5 c}$ ), benzyl (4d and $\mathbf{5 d}$ ), and diisopropylphenyl (4f and 5f) substituents onto the tzNHC metal complex. Furthermore, as a proof of principle that the methodology can be extended to incorporate biologically relevant functional groups such as glucosyl-based moieties, we also synthesised compounds containing a 2,3,4,6-tetra- $O$-acetyl- $\beta$-D-glucopyranosyl group as a substituent on the tzNHC (4e and $5 \mathbf{e})$. All the metal compounds were isolated as yellow to orange solids which were soluble in a range of solvents $\left(\mathrm{MeOH}, \mathrm{CH}_{2} \mathrm{Cl}_{2}, \mathrm{MeCN}\right.$, acetone, DMSO), and in addition, the presence of the carbohydrate substituent on $\mathbf{4 e}$ and $\mathbf{5 e}$ imparted good water solubility to the complexes.

Characterisation data corroborate the expected structures of the metal carbene complexes. Namely, the pre-carbene proton of the triazolium salts $3 \mathbf{a}-\mathbf{f}\left(\mathrm{H}-1, c a .8 .6-8.8 \mathrm{ppm}, \mathrm{CDCl}_{3}, \mathrm{ESI} \dagger\right)$

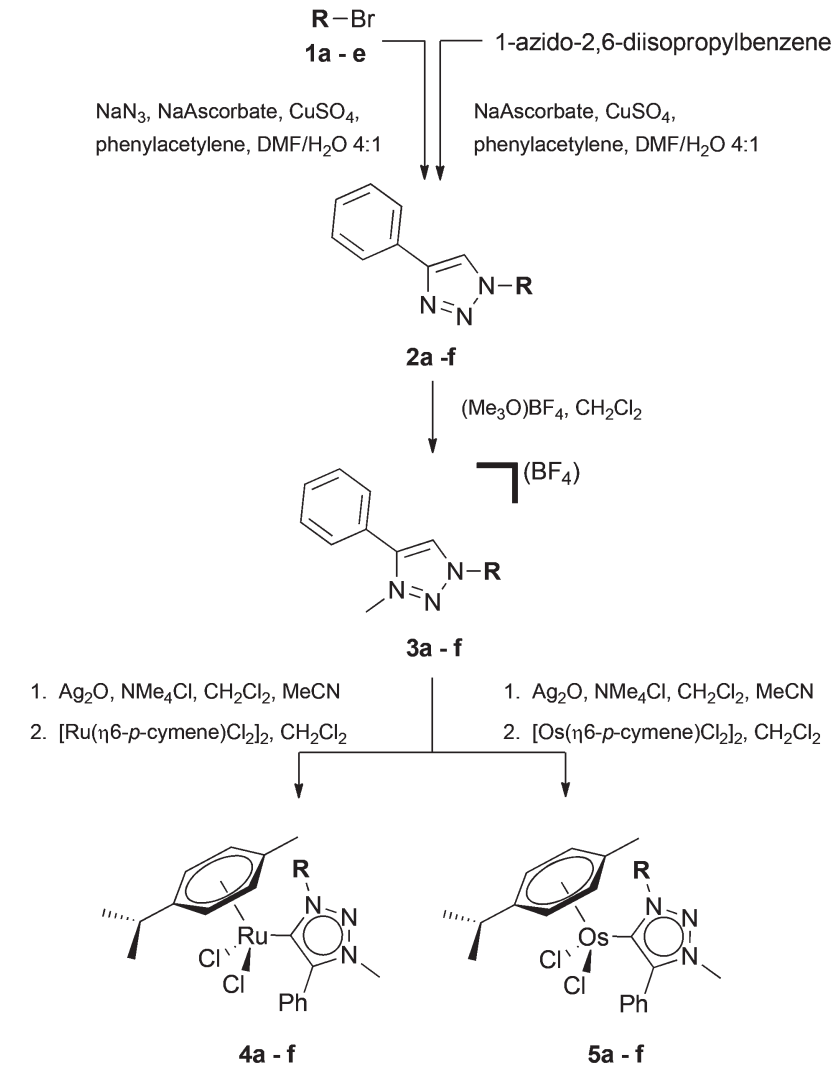

Scheme 1 Route used to prepare $\mathrm{Ru}(I)$ and Os(I) 1,2,3-triazolylidene NHC complexes. 1a/2a/3a/4a/5a: $\mathrm{R}=$ ethyl; $1 \mathrm{~b} / 2 \mathrm{~b} / 3 \mathrm{~b} / 4 \mathrm{~b} / 5 \mathrm{~b}: \mathrm{R}=n$-hexyl; $1 c / 2 c / 3 c / 4 c / 5 c: R=n$-dodecyl; $1 d / 2 d / 3 d / 4 d / 5 d: R=$ benzyl; $1 \mathrm{e} / 2 \mathrm{e} / 3 \mathrm{e} /$ 4e/5e: $R=2,3,4,6$-tetra-O-acetyl- $\beta$-D-glucopyranosyl; $2 \mathrm{f} / 3 \mathrm{f} / 4 \mathrm{f} / 5 \mathrm{f}$ : $\mathrm{R}=2,6$-diisopropylphenyl.

is no longer present in the ${ }^{1} \mathrm{H}$ NMR spectra of the metal complexes $4 \mathbf{a}-\mathbf{e}$ and $\mathbf{5 a}-\mathbf{e}$, and the alpha protons on the N1 triazolylidene substituent show a slight downfield shift (ca. $0.2 \mathrm{ppm})$ in the ${ }^{1} \mathrm{H}$ NMR spectra relative to the triazolium salt precursors 3a-e. The ${ }^{13} \mathrm{C}\left\{{ }^{1} \mathrm{H}\right\}$ chemical shift of the carbene centre (C-1) differs slightly for the ruthenium (ca. $160 \mathrm{ppm}$ ) and osmium (ca. $148 \mathrm{ppm}$ ) complexes.

The main ion observed in the ESI mass spectra of the complexes arises from fragmentation via the loss of a chloride ligand to give $[\mathrm{M}-\mathrm{Cl}]^{+}$type species.

The molecular structure of $\mathbf{5 d}$ was unequivocally verified by single crystal X-ray crystallography on crystals grown at $4{ }^{\circ} \mathrm{C}$ by the slow diffusion of diethylether into a dichloromethane solution of $\mathbf{5 d}$. The molecular structure of $\mathbf{5 d}$ is shown in Fig. 2 and selected bond parameters are given in the caption.

As expected, the complex adopts a piano-stool motif, comprising the $p$-cymene 'seat', with the two chloride ligands and the tzNHC ligand representing the three 'legs'. The Os-tzNHC bond length $[\mathrm{Os}(1)-\mathrm{C}(1)]$ is $2.068(10) \AA$, with the benzyl N(1) substituent orientated in such a manner to minimize interactions with the $p$-cymene ring. The Os $\cdots p$-cymene centroid distance is $[1.675(5) \AA]$, with no appreciable tilt or offsetting of the $p$-cymene ring observed. 


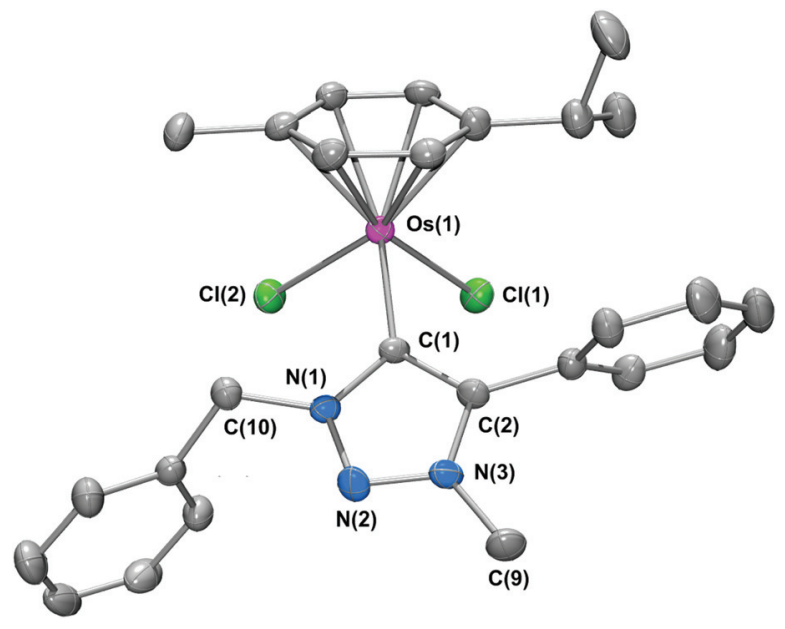

Fig. 2 Molecular structure of $5 \mathrm{~d} \cdot \mathrm{CH}_{2} \mathrm{Cl}_{2}$ with selected atom labelling Hydrogen atoms and the $\mathrm{CH}_{2} \mathrm{Cl}_{2}$ solvate have been omitted for clarity. Thermal ellipsoids are drawn at 30\% probability. Selected bond lengths ( $\AA$ ) and angles ( ${ }^{\circ}$ : Os(1)-C(1) 2.068(10), Os(1)-Cl(1) 2.420(3), Os(1)-Cl(2) 2.445(3); $\mathrm{C}(1)-\mathrm{Os}(1)-\mathrm{Cl}(1)$ 85.7(3), C(1)-Os(1)-Cl(2) 90.9(3), Cl(1)-Os(1)-Cl(2) 82.53(11).

\section{Behaviour in solution}

The chloride ligand(s) of ruthenium arene compounds such as those of the RAPTA and [Ru-arene-en] ${ }^{+}$series (Fig. 1) undergo hydrolysis in aqueous solution, giving aquated species, which are proposed to be the active form of the compounds inside cells. $^{29,30}$ The rate of this hydrolysis process has been suggested to influence the biological activity of ruthenium drugs therefore, it is useful to evaluate the behaviour of new compounds under pseudo-physiological conditions. ${ }^{31,32}$ As such, the solution characteristics of the new ruthenium(II) and osmium(II) tzNHC complexes were probed by a combination of UV-Vis spectroscopy and ${ }^{1} \mathrm{H}$ NMR spectroscopy, and compared to the RAPTA series of compounds, in particular RAPTA-C, $\left(\left[\operatorname{Ru}\left(\eta^{6}-p\right.\right.\right.$-cymene $\left.) \mathrm{Cl}_{2}(\mathrm{PTA})\right]$, due to the structural similarity. In aqueous phosphate buffered solution $(10 \mathrm{mM}$, $\mathrm{pH}$ 7.4), the UV-Vis spectra of $4 \mathbf{e}$ was stable and unchanged from the initial solution over a period of 7 days. However, the UV-Vis trace differed when the spectrum was acquired in saline phosphate buffered solution $\left(10 \mathrm{mM}, \mathrm{pH} 7.4,\left[\mathrm{Cl}^{-}\right]\right.$ $150 \mathrm{mM}$ ), indicating that under the former conditions hydrolysis of one, or both, of the chloride ligand(s) had already taken place. Unlike RAPTA-C, which reaches an equilibrium after $\mathrm{ca} .20 \mathrm{~min},{ }^{29}$ hydrolysis of $4 \mathbf{e}$ must be very rapid. Moreover, as with RAPTA-C, the process is suppressed under relatively high physiological chloride concentrations. Furthermore, although the ${ }^{1} \mathrm{H}$ NMR spectrum of $4 \mathbf{e}\left(\mathrm{D}_{2} \mathrm{O}\right)$ is rather complicated due to the presence of a number of different species (tentatively assigned as hydrolysis products with the loss of either one or both chloride ligands), there was no evidence to suggest the loss of either the $p$-cymene or tzNHC ligands. The electrospray mass spectra of an aqueous solution of $4 \mathbf{e}$ also provides evidence which points towards the loss of one or both of the chloride ligands, with the ions corresponding to both $[\mathbf{4 e}-\mathrm{Cl}]^{+}$and $[\mathbf{4 e}-2 \mathrm{Cl}]^{2+}$ species present (see ESI $\dagger$ ). As with $\mathbf{4 e}$, the osmium(II) complex 5e also appears to undergo immediate hydrolysis in aqueous phosphate buffered solution.

\section{Biological activity}

The biological activity of the compounds was initially explored by determining their cytotoxicity against two human tumour (A2780 and A2780R) and non-tumour (HEK) cell lines (Table 1).

The new complexes show promising activity profiles, notably, a number of compounds display low micromolar activity against the tumour cell lines $(<1 \mu \mathrm{M})$, which contrasts with other bifunctional ruthenium arene compounds such as RAPTA-C. ${ }^{33}$ This difference may be related to the relatively fast hydrolysis process, at least in part, as relationships between the rate of hydrolysis (activation) and cytotoxicity have been demonstrated. ${ }^{34}$ Importantly, in all cases the tzNHC complexes show selectivity towards the tumour cell lines (A2780 and A2780R) over the non-tumourigenic HEK cell line - this is exemplified by $\mathbf{4 a}$ which has a $c a$. 200-fold selectivity for the A2780 cell line over the HEK cell line. In addition, such a marked in vitro selectivity profile in this assay shows improvements over the selectivity characteristics of cisplatin. It is also evident that increasing the lipophilicity of the complex (brought about by modifying the tzNHC alkyl sidechain) influences the in vitro activity of the complexes, ${ }^{35}$ with the activity trends being $\mathbf{4 a}<\mathbf{4 b}<\mathbf{4 c}$ and $\mathbf{5 a}<\mathbf{5 b}<\mathbf{5 c}$, presumably due to increased uptake into cells. ${ }^{36}$ The relationship between the metal ion employed, i.e. Ru(II) vs. Os(II), and the cytotoxicity for the reported tzNHC complexes follows no obvious trends, and prediction of the level of biological activity upon switching the metal centre from $\mathrm{Ru}$ (II) to Os(II) is not straightforward. For example, whilst the in vitro cytotoxicity of RAPTA-C and OsAPTA-C ([Os $\left(\eta^{6}-p\right.$-cymene $\left.) \mathrm{Cl}_{2}(\mathrm{PTA})\right]$ is of a similar order of magnitude, ${ }^{37}$ when the PTA ligand is replaced by a carbohydrate-based phosphine in a similar series of compounds, the $\mathrm{Ru}$ (II) complexes are more active than the Os(II) analogues. ${ }^{38}$

As RAPTA complexes are believed to interact with proteins in preference to DNA, ${ }^{39}$ we also probed the interaction of $\mathbf{4 b}$ with the model protein ubiquitin (Ub) using HR-ESI mass

Table 1 Cytotoxicity $\left(\mathrm{IC}_{50}, \mu \mathrm{M}\right)$ of selected compounds at $72 \mathrm{~h}$

\begin{tabular}{llll}
\hline & $\mathrm{A}^{2} 780^{a}$ & $\mathrm{~A}^{a} 780 \mathrm{R}^{b}$ & $\mathrm{HEK}^{c}$ \\
\hline $\mathbf{4 a}$ & $1.85 \pm 0.29$ & $25.6 \pm 5.5$ & $435 \pm 25$ \\
$\mathbf{5 a}$ & $27.8 \pm 12.3$ & $112 \pm 13$ & $168 \pm 11$ \\
$\mathbf{4 b}$ & $0.31 \pm 0.08$ & $1.77 \pm 0.04$ & $29.0 \pm 1.8$ \\
$\mathbf{5 b}$ & $4.97 \pm 0.03$ & $14.2 \pm 3.3$ & $16.5 \pm 1.4$ \\
$\mathbf{4 c}$ & $0.12 \pm 0.02$ & $0.23 \pm 0.02$ & $1.80 \pm 0.20$ \\
$\mathbf{5 c}$ & $0.12 \pm 0.02$ & $0.33 \pm 0.06$ & $2.59 \pm 0.34$ \\
$\mathbf{4 d}$ & $4.82 \pm 0.12$ & $37.8 \pm 7.8$ & $64.0 \pm 6.1$ \\
$\mathbf{5 d}$ & $1.41 \pm 0.06$ & $2.36 \pm 0.46$ & $31.7 \pm 5.0$ \\
$\mathbf{4 e}$ & $41.0 \pm 8.2$ & $>200$ & $>200$ \\
$\mathbf{5 e}$ & $19.9 \pm 2.3$ & $105 \pm 5$ & $>200$ \\
$\mathbf{4 f}$ & $0.21 \pm 0.05$ & $1.10 \pm 0.12$ & $1.85 \pm 0.12$ \\
$\mathbf{5 f}$ & $0.13 \pm 0.03$ & $0.21 \pm 0.01$ & $2.89 \pm 0.03$ \\
$\mathbf{C i s p l a t i n}$ & $4.3 \pm 0.5$ & $18.2 \pm 1.0$ & $15.3 \pm 0.5$
\end{tabular}

${ }^{a}$ Human ovarian carcinoma cells. ${ }^{b}$ Human ovarian carcinoma cells acquired resistance to cisplatin. ${ }^{c}$ Human embryonic kidney cells. 


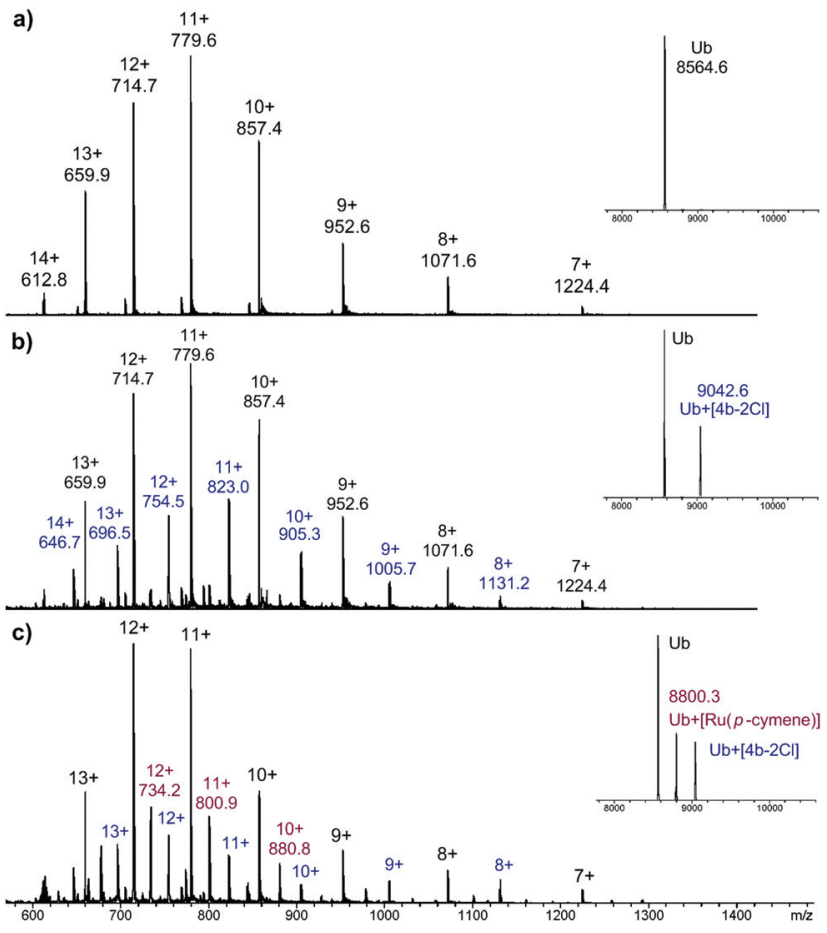

Fig. 3 ESI mass spectra of (a) Ub; (b) $U b+4 b$, (1:5 ratio) 1 day incubation and (c) Ub $+4 b$, (1:5 ratio) 5 day incubation, with deconvoluted mass spectra shown as insets.

spectrometry. Complex $\mathbf{4 b}$ was incubated with $\mathrm{Ub}(5: 1)$ at $37^{\circ} \mathrm{C}$ and the mass spectra were recorded after 1 and 5 days (Fig. 3).

After 1 day, peaks corresponding to a 1:1 Ub-complex adduct is observed, assigned as $\mathrm{Ub}+[\mathbf{4 b}-2 \mathrm{Cl}]$, with the tzNHC fragment still bound to the metal centre. After 5 days, partial loss of the tzNHC ligand was observed, and although $\mathbf{4 b}$ was present in excess, the mass spectrum still indicated the presence of unmodified Ub. This reactivity is quite distinct to that of RAPTA-C (see ESI $\dagger$ ), which reacts far more readily with Ub, with loss of the pta ligand observed after 1 day, and prolonged incubation leading to the complete disappearance of free Ub. The osmium(II) tzNHC complex responded differently again, and was not found to coordinate to Ub under the employed conditions (see ESI $\dagger$ ). The low reactivity of the tzNHC compounds towards Ub, and presumably other relevant proteins, may prove advantageous, as with some drugs (in particular cisplatin), interactions with proteins are believed to deactivate the drug and/or lead to adverse side effects. ${ }^{40}$

\section{Conclusions}

For the first time, we have demonstrated that the relatively new tzNHC ligands offer considerable potential in medicinal inorganic/organometallic chemistry. The ruthenium(II) and osmium(II) $\eta^{6}$-arene complexes with these ligands show an excellent activity profile against a range of cell lines, and in some instances, such as compound 4a, show excellent selectivity towards tumour cell lines over non tumour lines. In keeping with previously studied $\mathrm{Ru}(\mathrm{II})$ arene complexes, the tzNHC examples also undergo hydrolysis in aqueous solution, but in contrast, do not react with model proteins such as Ub as readily. Different groups can be easily introduced onto the tzNHC ligand via the initial CuAAC click reaction. Thus, a number of different functionalities, e.g. targeting groups, enzyme inhibitors, optically active fluorophores/lumophores, may be introduced, allowing diversity to be included in the complexes, an important aspect with respect to drug discovery.

\section{Experimental}

\section{General}

$\left[\mathrm{Ru}\left(\eta^{6}-p \text {-cymene }\right) \mathrm{Cl}_{2}\right]_{2},{ }^{41}$ and $\left[\mathrm{Os}\left(\eta^{6}-p \text {-cymene }\right) \mathrm{Cl}_{2}\right]_{2},{ }^{42}$ were prepared using literature procedures, all other reagents and solvents were obtained from commercial sources and used without further purification. The general synthetic protocol for the synthesis of the metal tzNHC complexes $\mathbf{4 a - f}$ and $\mathbf{5 a}-\mathbf{f}$ is outlined below, full synthetic details and characterisation data for all compounds in this study (including 1,4-disubstituted-12-3-triazoles $\mathbf{2 a - f}$ and the corresponding triazolium salts $\mathbf{3 a - f}$ ) are included in the ESI. $\dagger$

\section{General synthetic procedure for $\mathrm{Ru}(\mathrm{II})$ and $\mathrm{Os}$ (II) tzNHC complexes $4 a-f$ and $5 a-f$}

The triazolium salt ( 1 equiv.), $\mathrm{Ag}_{2} \mathrm{O}$ (0.5 equiv.) and $\mathrm{NMe}_{4} \mathrm{Cl}$ (1 equiv.) were stirred in $\mathrm{CH}_{2} \mathrm{Cl}_{2}-\mathrm{MeCN}(1: 1,10 \mathrm{~mL})$ in a foilcovered flask for $18 \mathrm{~h}$ to give a cloudy white solution. The solvent was removed and the residue redissolved in $\mathrm{CH}_{2} \mathrm{Cl}_{2}$. $\left[\mathrm{M}\left(\eta^{6}-p \text {-cymene }\right) \mathrm{Cl}_{2}\right]_{2}(\mathrm{M}=\mathrm{Ru}$ or $\mathrm{Os})(0.5$ equiv. $)$ was added and the solution stirred for a further $90 \mathrm{~min}$. The solution was then filtered through a short column of celite to remove the salt by-products, concentrated under reduced pressure and precipitated with either $\mathrm{Et}_{2} \mathrm{O}$ or hexane at $-4{ }^{\circ} \mathrm{C}$. The solid was isolated by filtration, washed with either $\mathrm{Et}_{2} \mathrm{O}$ or hexane and dried in vacuo.

\section{X-Ray crystallography}

Single crystal X-ray diffraction data for $\mathbf{5 d} \cdot \mathbf{C H}_{2} \mathrm{Cl}_{2}$ were collected using graphite monochromated $\mathrm{Cu} K \alpha$ radiation $(\lambda=$ $1.54180 \AA$ A) on an Agilent Technologies SuperNova dual system in combination with an Atlas CCD detector. Data reduction was carried out using Crysalis PRO. ${ }^{43}$ The structure was solved by direct methods (SHELXS-97) and refined against all $F^{2}$ data (SHELXL-97 and Shelxle). ${ }^{44,45}$ Non-hydrogen atoms were refined with anisotropic displacement parameters. Hydrogen atoms were positioned geometrically and refined using a riding model with $d\left(\mathrm{CH}_{\text {aro }}\right)=0.93 \AA, U_{\text {iso }}=1.2 U_{\text {eq. }}(\mathrm{C})$ for aromatic, $d(\mathrm{CH})=0.98 \AA, U_{\text {iso }}=1.2 U_{\text {eq. }}(\mathrm{C})$ for $\mathrm{CH}, 0.97 \AA$, $U_{\text {iso }}=1.2 U_{\text {eq. }}(\mathrm{C})$ for $\mathrm{CH}_{2}$ and $0.96 \AA, U_{\text {iso }}=1.2 U_{\text {eq. }}(\mathrm{C})$ for $\mathrm{CH}_{3}$ (Table 2).

\section{Cell culture conditions and cytotoxicity assay}

Human A2780 and A2780cisR ovarian carcinoma and HEK (human embryonic kidney) cells were obtained from the 
Table 2 Crystal data and structure refinement parameters for 5d. $\mathrm{CH}_{2} \mathrm{Cl}_{2}$
CCDC code

Empirical formula

Formula weight

Temperature

Wavelength

Crystal system

Unit cell dimensions

Volume

Z

Density (calculated)

Absorption coefficient

$F(000)$

Crystal size

Theta range for data collection

Index ranges

Reflections collected

Independent reflections

Completeness to theta $=$

$67.48^{\circ}$

Absorption correction

Max. and min. transmission

Refinement method

Data/restraints/parameters

Goodness-of-fit on $F^{2}$

Final $R$ indices $[I>2 \sigma(I)]$

$R$ indices (all data)

Largest diff. peak and hole
Space group

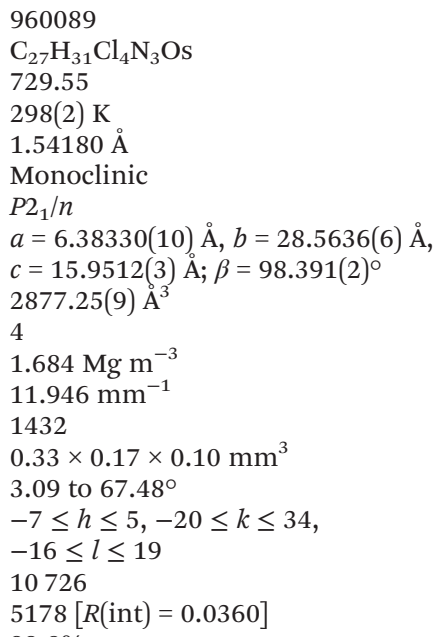

Semi-empirical from equivalents 0.3919 and 0.1083

Full-matrix least-squares on $F^{2}$ $5178 / 0 / 317$

1.192

$R_{1}=0.0641, \mathrm{w} R_{2}=0.1693$

$R_{1}=0.0713, \mathrm{w} R_{2}=0.1732$

2.700 and -2.486 e $\AA^{-3}$
European Collection of Cell Cultures (Salisbury, UK). A2780 and A2780R cells were grown routinely in RPMI-1640 medium, while HEK cells were grown with DMEM medium, with $10 \%$ foetal calf serum (FCS) and antibiotics at $37{ }^{\circ} \mathrm{C}$ and $5 \% \mathrm{CO}_{2}$. Cytotoxicity was determined using the MTT assay (MTT = 3(4,5-dimethyl-2-thiazolyl)-2,5-diphenyl-2 $\mathrm{H}$-tetrazolium bromide). Cells were seeded in 96-well plates as monolayers with $100 \mu \mathrm{L}$ of cell solution (approximately 20000 cells) per well and preincubated for $24 \mathrm{~h}$ in medium supplemented with $10 \%$ FCS. Compounds were prepared as DMSO solutions then immediately dissolved in the culture medium and serially diluted to the appropriate concentration, to give a final DMSO concentration of $0.1 \% .100 \mu \mathrm{L}$ of drug solution was added to each well and the plates were incubated for another $72 \mathrm{~h}$. Subsequently, MTT ( $5 \mathrm{mg} \mathrm{mL} \mathrm{mL}^{-1}$ solution) was added to the cells and the plates were incubated for a further $2 \mathrm{~h}$. The culture medium was aspirated, and the purple formazan crystals formed by the mitochondrial dehydrogenase activity of vital cells were dissolved in DMSO. The optical density, directly proportional to the number of surviving cells, was quantified at $590 \mathrm{~nm}$ using a multiwell plate reader and the fraction of surviving cells was calculated from the absorbance of untreated control cells. Evaluation is based on means from at least two independent experiments, each comprising three microcultures per concentration level.

\section{Ubiquitin binding studies}

The compound was incubated with Ubiquitin (from bovine red blood cells, min 90\%, Sigma Aldrich) in MilliQ water at a molar ratio of $5: 1$ at $37^{\circ} \mathrm{C}$. Immediately prior to analysis, an aliquot of the incubation solution was diluted with water-acetonitriletrifluoroacetic acid (50:50:0.1) to yield a final protein concentration of $0.5 \mu \mathrm{M}$, and introduced by direct infusion into the ESI source of the mass spectrometer at a flow rate of $5 \mu \mathrm{L} \min ^{-1}$ (source voltage, $+4.5 \mathrm{kV}$; capillary temperature, $180{ }^{\circ} \mathrm{C}$; sheath gas flow, $4 \mathrm{~L} \mathrm{~min}^{-1}$ ). Data were processed with DataAnalysis 4.0 SP5 software (Bruker Daltonics).

\section{Acknowledgements}

This work was supported by the New Zealand Ministry of Business, Innovation and Employment (formally Foundation of Research, Science and Technology Postdoctoral Fellowship, EPFL1001, to KJK) and the EPFL. We thank Dr R. Scopelliti for the collection of the X-ray data set.

\section{Notes and references}

1 N. J. Wheate, S. Walker, G. E. Craig and R. Oun, Dalton Trans., 2010, 39, 8113-8127.

2 G. Gasser, I. Ott and N. Metzler-Nolte, J. Med. Chem., 2010, 54, 3-25.

3 J. M. Rademaker-Lakhai, D. van den Bongard, D. Pluim, J. H. Beijnen and J. H. M. Schellens, Clin. Cancer Res., 2004, 10, 3717-3727.

4 C. G. Hartinger, M. A. Jakupec, S. Zorbas-Seifried, M. Groessl, A. Egger, W. Berger, H. Zorbas, P. J. Dyson and B. K. Keppler, Chem. Biodiversity, 2008, 5, 2140-2155.

5 A. Bergamo, C. Gaiddon, J. H. M. Schellens, J. H. Beijnen and G. Sava, J. Inorg. Biochem., 2012, 106, 90-99.

6 W. H. Ang and P. J. Dyson, Eur. J. Inorg. Chem., 2006, 39933993.

7 W. H. Ang, A. Casini, G. Sava and P. J. Dyson, J. Organomet. Chem., 2011, 696, 989-998.

8 P. C. A. Bruijnincx and P. J. Sadler, Adv. Inorg. Chem., 2009, 61, 1-62.

9 B. Therrien, Coord. Chem. Rev., 2009, 253, 493-519.

10 G. S. Smith and B. Therrien, Dalton Trans., 2011, 40, 10793-10800.

11 G. C. Vougioukalakis and R. H. Grubbs, Chem. Rev., 2010, 110, 1746-1787.

12 W. Liu and R. Gust, Chem. Soc. Rev., 2013, 42, 755-773.

13 A. Gautier and F. Cisnetti, Metallomics, 2012, 4, 23-32.

14 L. Mercs and M. Albrecht, Chem. Soc. Rev., 2010, 39, 19031912.

15 L. Oehninger, H. Alborzinia, S. Ludewig, K. Baumann, S. Wölfl and I. Ott, ChemMedChem, 2011, 6, 2142-2145.

16 L. Oehninger, M. Stefanopoulou, H. Alborzinia, J. Schur, S. Ludewig, K. Namikawa, A. Munoz-Castro, R. W. Koster, K. Baumann, S. Wolfl, W. S. Sheldrick and I. Ott, Dalton Trans., 2013, 1657-1666. 
17 J. M. Alfaro, A. Prades, M. del Carmen Ramos, E. Peris, J. Ripoll-Gómez, M. Poyatos and J. S. Burgos, Zebrafish, 2010, 7, 13-21.

18 P. Mathew, A. Neels and M. Albrecht, J. Am. Chem. Soc., 2008, 130, 13534-13535.

19 J. D. Crowley, A.-L. Lee and K. J. Kilpin, Aust. J. Chem., 2011, 64, 1118-1132.

20 K. F. Donnelly, A. Petronilho and M. Albrecht, Chem. Commun., 2013, 49, 1145-1159.

21 H. C. Kolb, M. G. Finn and K. B. Sharpless, Angew. Chem., Int. Ed., 2001, 40, 2004-2021.

22 M. Meldal and C. W. Tornøe, Chem. Rev., 2008, 108, 29523015.

23 K. J. Kilpin, E. L. Gavey, C. J. McAdam, C. B. Anderson, S. J. Lind, C. C. Keep, K. C. Gordon and J. D. Crowley, Inorg. Chem., 2011, 50, 6334-6346.

24 K. J. Kilpin and P. J. Dyson, Chem. Sci., 2013, 4, 1410-1419.

25 D. Yuan and H. V. Huynh, Organometallics, 2012, 31, 405412.

26 J. D. Crowley, P. H. Bandeen and L. R. Hanton, Polyhedron, 2010, 29, 70-83.

27 J. D. Crowley and P. H. Bandeen, Dalton Trans., 2010, 39, 612-623.

28 K. J. Kilpin, U. S. D. Paul, A.-L. Lee and J. D. Crowley, Chem. Commun., 2011, 47, 328-330.

29 C. Scolaro, C. G. Hartinger, C. S. Allardyce, B. K. Keppler and P. J. Dyson, J. Inorg. Biochem., 2008, 102, 1743-1748.

30 K. J. Kilpin, S. M. Cammack, C. M. Clavel and P. J. Dyson, Dalton Trans., 2013, 42, 2008-2014.

31 W. H. Ang, E. Daldini, C. Scolaro, R. Scopelliti, L. JuilleratJeannerat and P. J. Dyson, Inorg. Chem., 2006, 45, 9006-9013.

32 F. Wang, A. Habtemariam, E. P. L. van der Geer, R. Fernández, M. Melchart, R. J. Deeth, R. Aird, S. Guichard, F. P. A. Fabbiani, P. Lozano-Casal,
I. D. H. Oswald, D. I. Jodrell, S. Parsons and P. J. Sadler, Proc. Natl. Acad. Sci. U. S. A., 2005, 102, 18269-18274.

33 W. H. Ang, Ecole Polytechnique Federale de Lausanne (EPFL), PhD Thesis, 2007.

34 A. F. A. Peacock, S. Parsons and P. J. Sadler, J. Am. Chem. Soc., 2007, 129, 3348-3357.

35 A. K. Renfrew, L. Juillerat-Jeanneret and P. J. Dyson, J. Organomet. Chem., 2011, 696, 772-779.

36 A. Kurzwernhart, W. Kandioller, C. Bartel, S. Bächler, R. Trondl, G. Mühlgassner, M. A. Jakupec, V. B. Arion, D. Marko, B. K. Keppler and C. G. Hartinger, Chem. Commun., 2012, 48, 4839-4841.

37 A. Dorcier, W. H. Ang, S. Bolaño, L. Gonsalvi, L. JuilleratJeannerat, G. Laurenczy, M. Peruzzini, A. D. Phillips, F. Zanobini and P. J. Dyson, Organometallics, 2006, 25, 4090-4096.

38 M. Hanif, A. A. Nazarov, C. G. Hartinger, W. Kandioller, M. A. Jakupec, V. B. Arion, P. J. Dyson and B. K. Keppler, Dalton Trans., 2010, 39, 7345-7352.

39 B. Wu, M. S. Ong, M. Groessl, Z. Adhireksan, C. G. Hartinger, P. J. Dyson and C. A. Davey, Chem.-Eur. J., 2011, 17, 3562-3566.

40 A. R. Timerbaev, C. G. Hartinger, S. S. Aleksenko and B. K. Keppler, Chem. Rev., 2006, 106, 2224-2248.

41 M. A. Bennett and A. K. Smith, J. Chem. Soc., Dalton Trans., 1974, 233-241.

42 H. Werner and K. Zenkert, J. Organomet. Chem., 1988, 345, 151-166.

43 Crysalis PRO, release 1.171.35.21, Agilent Technologies, 2012.

44 G. M. Sheldrick, Acta Crystallogr., Sect. A: Fundam. Crystallogr., 2008, 64, 112-122.

45 C. B. Hübschle, G. M. Sheldrick and B. Dittrich, J. Appl. Crystallogr., 2011, 44, 1281-1284. 